\title{
Association of Leptin Promoter 2548G/A variant with Serum Leptin, Lipid Profile and Type 2 Diabetes Mellitus
}

Gaylany $\mathbf{H}$ Abdullah $(\mathrm{PhD})^{1}$

Abstract

Background: A common 2548G/A promoter variant of the human leptin gene has been implicated in circulating leptin levels variations and pathogenesis of type 2 diabetes mellitus but available data are still conflicting.

Objective: To explore potential associations between LEP 2548G/A of leptin with T2DM and the effect of this variation on serum leptin levels.

Patients and Methods: Sixty two patients with T2DM and fifty non-diabetic controls were included in the study. Blood samples were collected from subjects for biochemical analysis and Genotyping was performed by polymerase chain reaction reaction-restriction fragment length polymorphism (PCR-RFLP).

Results: The genotype frequencies for LEP 2548G/G, LEP 2548G/A LEP 2548A/A were 46\%, $32 \%$ and $22 \%$ in control group, and $19.4 \%, 33.9 \%$ and $46.7 \%$ in diabetic group, respectively. The A allele and GA/AA genotype of LEP 2548G/A was found to be more frequent than the G allele and GG genotype in T2DM patients compares to the controls. Subjects with the GA + AA genotype of LEP 2548G/A were at increased risk for T2DM $(\mathrm{P}=0.0001$, OR $=1.78$; 95\% CI: 1.19-2.38). The serum leptin concentration of GA + AA genotype carriers was significantly higher from that of the GG genotype in the diabetic group.

Conclusion: A allele carrier who have higher serum concentrations of leptin may have an association with the risk of T2DM development in the Erbi population.

Keywords: Leptin, single nucleotide polymorphism, polymerase chain reaction- restriction fragment length polymorphism,T2DM.

Corresponding Author: mbiophysics@gmail.com

Received: $11^{\text {th }}$ March 2020

Accepted: $30^{\text {th }}$ August 2020

DOI:https://doi.org/10.26505/DJM.19015300311

\section{Introduction}

Leptin is a metabolic and neuroendocrine hormone encoded by the obese gene that is synthesized and released mainly by adipocytes [1,2] and its serum levels correlate positively with body fat mass and body mass index (BMI). The leptin gene promoter (LEP) is present on $7 \mathrm{q} 31.3$ chromosomal region and comprises three exons intervened by two introns [3]. The gene was identified in 1994 by positional cloning [4]. The (LEP) variant 2548 G/A (rs7799039) is an LEP gene single nucleotide 
polymorphism (SNP) consisting of $\mathrm{G}$ to $\mathrm{A}$ substitution at nucleotide 2548 upstream of the ATG start site in the LEP. The polymorphism LEP 2548G/A in the $5^{\prime}$ untranslated region of the leptin gene has been described in detail in a number of studies, and believed that this variant may directly affect transcriptional level by the adipose tissue and potentially related to the pathophysiology of diabetes, and associated complications $[5,6,7]$. Type 2 diabetes mellitus (T2DM) is a complex disease characterised by hyperglycaemia and altered lipid metabolism due to impaired insulin secretion from pancreatic $\beta$-cells and both environmental and genetic factors can be a factor to disease initiation as well as its evolution. Genome wide association studies have discovered more than 40 polymorphisms associated with an increased risk for the disease and LEP 2548 G/A polymorphism is the most greatly studied one [8-12]. The aim of our study was to reveal any possible associations of LEP (2548G/A) gene with T2DM and selected serum biochemical parameters in Kurdish volunteers, hence such data is missing in mentioned populations.

\section{Patients and Methods Study subjects}

The present study was performed in a sample of 112 adults who were chosen at random. The subjects ranged in age from 42 to 70 years, Body mass index (BMI) is taken from each participant and calculated as weight $(\mathrm{kg})$ divided by height $(\mathrm{m})$ squared. Subjects in this study were classified as normal group (control group / non-diabetic group $n=50$ ) and patients with T2DM (diabetic group $n=62$ ), pregnant females were excluded from the study.

\section{Biochemical parameters determination}

Blood samples were collected from subjects after a $12 \mathrm{~h}$ overnight fast. Serum samples were analysed for Fasting blood glucose (FBG), total cholesterol (TC), triglycerides (TG) using standard enzymatic techniques. [13-15]. High-density-lipoprotein (HDL) was determined after precipitation of apolipoprotein B-containing lipoproteins [16] and low-density lipoprotein (LDL-C) was determined according to the method of Hatch and Lees [17]. Insulin sensitivity was assessed by indirect HOMA-IR index [18]. Serum leptin concentration was measured by ELISA [19].

\section{Genotyping of G-2548A}

Genomic DNA was extracted from whole blood using Promega Wizard® Genomic DNA purification kit, was quantified using Nanodrop (NanoDrop1000 spectrophotometer V 3.7). Genotyping of $2548 \mathrm{G} / \mathrm{A}$ polymorphism in the LEP gene was carried out by polymerase chain reactionrestriction fragment length polymorphism assay (PCR-RFLP). A DNA fragment containing G-2548A polymorphism was amplified using specific primers, forward: 5'TTTCCTGTAATTTTCCCGTGAG-3' and reverse:5'AAAGCAAAGACAGGCATAAA AA-3'. PCR reactions were carried out in 25 $\mu \mathrm{l}$ volumes comprising $5 \mu \mathrm{l}$ of Taq Promega PCR reaction buffer $(5 \mathrm{x}), 1 \mu \mathrm{l}$ of each primer, $3 \mu$ l template DNA (50 ng) , $0.12 \mu \mathrm{l}$ 
of Taq DNA polymerase, and $14.4 \mu \mathrm{l}$ nuclease-free water,. The PCR reaction tubes were then placed in the thermal cycler (Perkin Elmer 9600). The PCR program consisted of an initial denaturation at $95^{\circ} \mathrm{C}$ for $3 \mathrm{~min}$ followed by 35 cycles of denaturation at $95{ }^{\circ} \mathrm{C}$ for $30 \mathrm{~s}$, annealing at $57{ }^{\circ} \mathrm{C}$ for $30 \mathrm{~s}$, and extension at $72{ }^{\circ} \mathrm{C}$ for 45 s. Final extension was conducted at $72{ }^{\circ} \mathrm{C}$ for 10 min. 421bp amplified products were digested with MspI (Thermo Scientific, USA) at $37 \mathrm{oC}$ for $2 \mathrm{hrs}$, presence of $\mathrm{G}$ allele creates a restriction site and the product is cut into two fragments, $294 \mathrm{bp}$ and $127 \mathrm{bp}$ while the presence of $A$ allele produced a single fragment of $421 \mathrm{bp}$. PCR and restriction products were separated on $2 \%$ agarose gel electrophoresis at $100 \mathrm{~V}$ for $45 \mathrm{~min}$ and analyzed under UV light after ethidium bromide staining.

\section{Statistical analysis}

Data analysis was done using SPSS version 11.5. Demographic details were compared using t-test for continuous data. Allele frequencies and genotype distribution of the

Table (1): Anthropometric and clinical parameters of the subjects

\begin{tabular}{||c||c|c|c||}
\hline Variables & Control & $\mathrm{T}_{2} \mathrm{DM}$ & $P$ value \\
\hline \hline Sex(M/F) & $21 / 29$ & $28 / 34$ & $\mathrm{NS}$ \\
\hline \hline Age/Year & $43.15 \pm 2.43$ & $51.18 \pm 1.06$ & $<0.05$ \\
\hline \hline BMI/Kg m2 & $27.01 \pm 08$ & $33.98 \pm 47$ & $<0.05$ \\
\hline \hline FBG mg/dl & $84 \pm 1.09$ & $211 \pm 4.86$ & 0.01 \\
\hline \hline Serum insulin/ $\mu \mathrm{lU} / \mathrm{ml}$ & $7.98 \pm 1.62$ & $16.02 \pm 0.76$ & 0.01 \\
\hline \hline Leptin $\mu \mathrm{g} / \mathrm{ml}$ & $8.07 \pm 1.43$ & $57.31 \pm 2.31$ & 0.01 \\
\hline \hline HOMA-IR index & $2.04 \pm 0.91$ & $9.06 \pm 1.12$ & $\leq 0.03$ \\
\hline \hline TC mg/dl & $148 \pm 5.22$ & $204 \pm 9.53$ & $<0.001$ \\
\hline \hline TG mg/dl & $109 \pm 4.18$ & $212 \pm 7.23$ & $<0.001$ \\
\hline \hline LDL mg/dl & $79 \pm 1.16$ & $151 \pm 1.06$ & $<0.001$ \\
\hline \hline HDL mg/dl & $46 \pm 2.28$ & $34 \pm 1.74$ & $<0.001$ \\
\hline
\end{tabular}

*T2DM - Type 2 diabetes mellitus, BMI - body mass index, FBG - fasting blood glucose, TG - triacylglycerol, TC - total cholesterol, , LDLlow-density lipoprotein, HDL- high-density lipoprotein

population were compared by Chi square and/or fisher's exact test .Odds ratios were calculated with a $95 \%$ confidence interval. In all cases statistical significance was determined at the $\mathrm{P}$ value $<0.05$ was considered to be statistically significant.

\section{Results}

Anthropometric and clinical data are shown in Table 1. Sex distribution did not reveal any significant difference, and diabetic subjects were older $(51.18 \pm 1.06, \mathrm{P}<0.05)$ than controls (43.15 \pm 2.43$)$. Diabetic individuals exhibited, BMI, FBG, insulin, leptin values higher than the non-diabetic group .HOMA-IR was significantly raised to $(9.06 \pm 1.12)$ in the diabetic group $(\mathrm{p} \leq 0.03)$ in comparison to the control group (2.04 \pm 0.91 ). Regarding lipid profile diabetic subjects had significantly higher TC, TG, LDL compared with control subjects. While HDL ( $\mathrm{p}<0.001)$ level was significantly lower compared with control subjects. T2DM is one of the major comorbidities of obesity and often co-exists with obesity [21]. 
The leptin gene promoter -LEP 2548G/A genotype was determined by PCR-RFLP. The common allele ( $G$ allele) with the presence of a MspI cutting site (presence of a $\mathrm{G}$ at position 2548) was designated and generates two fragments, $294 \mathrm{bp}$ and $127 \mathrm{bp}$, while the variant allele (A allele) lacking this site and produced a single fragment of 421 bp. Thus, The leptin gene promoter -LEP 2548G/A polymorphism results in three genotypes, wild type GG homozygous (294 bp and 127bp), AA homozygous mutant (421 bp) and GA heterozygous (421bp, 294bp, and 127bp) Figure (1).

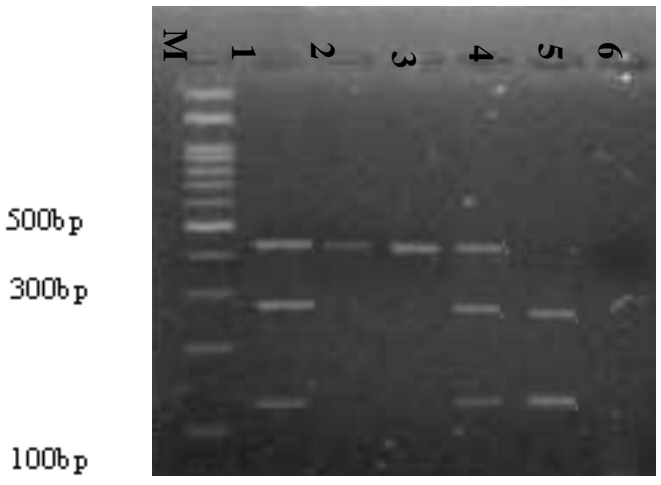

Figure (1): Agarose gel electrophoresis $2 \%$ stained with ethidium bromide showing the leptin gene amplification after RFLP. M - Molecular DNA marker. Lanes 1, and 4, - heterozygous GA (421, 294, 127 bp). Lanes 2- and 3- homozygous AA (421 bp). Lane 5 - homozygous GG (294, 127 bp) lane 6 (ve) control

Table (2) shows that diabetic group had a statistically significant lower distribution of the GG genotype than the control group $(19.4 \%$ and $46 \%$ respectively) and a statistically higher distribution of the GA/AA genotype than the control group (80.6\% and $54 \%$ respectively) $(\mathrm{p}=0.0001)$. Moreover, the results showed that the diabetic group had a statistically higher distribution of A allele frequency than the control group $(60.2 \%$ and $40.9 \%$ respectively) and a lower distribution of the $\mathrm{G}$ allele frequency than the control group (39.8\% and $59.1 \%$ respectively) $(\mathrm{p}=$ $0.001)$.

Table (2): Allele and Genotype frequencies of common and minor alleles of LEP 2548G/A polymorphism

\begin{tabular}{|c|c|c|c|c||}
\hline Allele/Genotype & Controls(n=50)\% & Diabetic(n=62)\% & OR (CI) & $P$ value \\
\hline \hline G & $39(59.1)$ & $33(39.8)$ & \multirow{2}{*}{$2.83(1.57-3.71)$} & \multirow{2}{*}{0.001} \\
\hline \hline A & $27(40.9)$ & $50(60.2)$ & & \multirow{2}{*}{0.0001} \\
\hline \hline GG & $23(46)$ & $12(19.4)$ & & \\
\hline \hline GA & $16(32)$ & $21(33.9)$ & \multirow{2}{*}{$1.78(1.19-2.38)$} & \\
\hline AA & $11(22)$ & $29(46.7)$ & & \\
\hline
\end{tabular}

* OR: Odds Ratio. CI: Confidence Intervals. a: GG vs. GA+AA, P-value Fisher`s Exact test. P-value Person Chi-Square test 
Relationship between LEP 2548G/A and serum leptin levels results given in Table (3) which revealed that the serum leptin concentration of GA + AA genotype carriers was not significantly different from that of the GG genotype in the control group. However, in the T2DM group serum levels of leptin of the GA + AA genotype were significantly higher than those of the GG genotype.

Table (3): Differences in serum leptin concentrations among different genotype carriers (GG or GA + AA) between control subjects and T2DM group

\begin{tabular}{|c|c|c|c|c|}
\hline Groups & Genotypes & $\mathrm{n}$ & Leptin $\mu \mathrm{g} / \mathrm{ml}$ & $P$ value \\
\hline \multirow{3}{*}{$\begin{array}{l}\text { Control } \\
\text { group }\end{array}$} & GG & 23 & $6.9 \pm 22$ & \\
\hline & GA & 17 & $8.01 \pm 14$ & NS \\
\hline & AA & 10 & $9.3 \pm 11$ & \\
\hline \multirow{3}{*}{$\begin{array}{l}\text { Diabetic } \\
\text { group }\end{array}$} & GG & 13 & $45.08 \pm 4.2$ & \\
\hline & GA & 20 & $58.42 \pm 5.03$ & 0.001 \\
\hline & AA & 29 & $68.43 \pm 5.98$ & \\
\hline
\end{tabular}

\section{Discussion}

The existence of polymorphisms in the promoter region of the human leptin gene has recently been associated with variations in circulating leptin levels, obesity and T2DM [20-21] among the variants identified in the 5 ' -flanking region of the leptin gene, the LEP $-2548 \mathrm{G} / \mathrm{A}$ polymorphism is the most greatly studied one but available data are still conflicting and studies had less power to provide us with dependable and comprehensive results due to varying sample size, ethnic differences, age, gender and different statistical procedure applied to investigate the relationships, Therefore, we investigated whether LEP 2548G/A polymorphisms and leptin serum levels are predictors for T2DM. Generally, most patients with diabetes are overweight or obese, in obese individuals' adipose tissue releases increased amounts of non-esterified fatty acids, glycerol, hormones, proinflammatory cytokines and other factors that are involved in the development of insulin resistance which are primary contributing factors to the development of T2DM [22-24]. Subjects with the AA genotype (Table 2) were at increased risk for T2DM $(\mathrm{OR}=1.78$, 95\% CI: 1.19- 2.38) compared with those having the GG genotype. This finding is consistent with data showing that the A allele of LEP $2548 \mathrm{G} / \mathrm{A}$ is significantly associated with T2DM. Leptin is a protein hormone transcribed by the leptin gene and synthesized by adipocytes, its expression and secretion are positively correlated with body fat mass and body mass index [25-28]. Leptin is the product of the obese gene (ob), and its concentration has been reported to be significantly elevated in obese and diabetic subjects compared to non-diabetic controls [29], which is reliable with our study (Table 3 ) that showed a significant increase in serum leptin levels in the diabetic group compared to the control group. The results suggest that 
increased leptin levels, probably reflecting leptin resistance, were strongly related to insulin resistance.

Different population's studies have described conflicting data on the association between the LEP 2548G/A variants and T2DM. In the present study, it seems that there is an association between the LEP 2548 G/A variant and T2DM. The AA genotype frequency was higher in diabetic group compared to the healthy subjects, and the A allele was more common in diabetic patients than the controls. Our results in agreement with the finding of other studies from different populations [30-33] interestingly the 2548G/A LEP SNP seem to affect leptin expression in adipose tissue [34-35]. Therefore, these data support the hypothesis that leptin polymorphisms affect leptin transcription and might play a role in the pathogenesis of T2DM.

\section{Conclusions}

In conclusion, LEP 2548G/A polymorphism is an important predictor for increased plasma leptin, lipid profile and BMI in kurdish population and it may be a useful marker for T2DM in this population.

\section{Recommendations}

It is highly recommended to employ the same study with large sample size in different ethnic groups, to better understand the role of leptin promoter in regulating lipid profile in human populations.

\section{References}

[1]Considine, RV. Sinha, MK. Heiman, ML. Kriauciunas, A. Stephens, TW. Nyce, MR. Ohannesian, JP. Marco, CC. McKee, LJ.
Bauer, TL. Serum immunoreactive-leptin concentrations in normal-weight and obese humans. N Engl J Med. 1996: 334, 292-295. [2]Considine, RV. Human leptin: an adipocyte hormone with weight-regulatory and endocrine functions. Semin Vasc Med. 2005: 5, 15-24.

[3]Luke, A.. Guo, X. Adeyemo, AA. Wilks, R. Forrester, T. Lowe, W. Jr. Comuzzie ,AG. Martin, LJ. Zhu, X. Rotimi, CN. Cooper, RS. Heritability of obesity-related traits among Nigerians, Jamaicans and US black people. Int J Obes Relat Metab Disord. 2001: 25: 1034-1041.

[4]Zhang, Y. Proenca, R. Maffei, M. Barone, M. Leopold, L.and Friedman, JM. Positionalcloning ofthe mouseobese geneand its human homologue. Nature. 1994:372, 425-432.

[5]Heo, M. Leibel, RL. Fontaine, KR. et al. A meta-analytic investigation of linkage and association of common leptin receptor (LEPR) polymorphisms with body mass index and waist circumference. Int $\mathrm{J}$ Obes. 2002:26, 640-646.

[6]Otero, M. Lago, R. Lago, F. Leptin, from fat to inflammation: old questions and new inslights. FEBS Lett. 2005:579, 295-301.

[7]Paracchini, V. Pedotti, P. Taioli, E. Genetics of leptin and obesity: a huge review. Am J Epidemiol. 2005:162, 101-114.

[8]Diabetes Genetics Initiative of Broad Institute of Harvard and MIT, Lund University, and Novartis Institutes of Bio Medical Research. Genome-wide association analysis identifies loci for type 2 diabetes and 
triglyceride levels. Science. 2007: 316, 1331 1336.

[9]Scott, LJ. Mohlke, KL. Bonnycastle, LL. Willer, CJ. Li, Y. Duren, WL. Erdos, MR. et al. A genome-wide association study of type 2 diabetes in Finns detects multiple susceptibility variants. Science. 2007: 316, 1341-1345.

[10] Sladek, R. Rocheleau, G. Rung, J. Dina, C. Shen, L. Serre, D. Boutin, P. Vincent, D. et al. A genome-wide association study identifies novel risk loci for type 2 diabetes. Nature. 2007: 445, 881-885.

[11]Zeggini, E. Weedon, MN. Lindgren, CM. Frayling, TM. Elliott, KS. Lango, $\mathrm{H}$. Timpson, NJ. et al. Wellcome Trust Case Control Consortium (WTCCC), McCarthy MI, Hattersley AT. Replication of genomewide association signals in UK samples reveals risk loci for type 2 diabetes. Science. 2007:316,1336-134.

[12] Zeggini, E. Scott, LJ. Saxena, R. Voight, BF. Marchini, JL. Hu, T. de Bakker, PI. et al. Meta-analysis of genome-wide association data and large-scale replication identifies additional susceptibility loci for type 2 diabetes. Nat Genet. 2008:40, 638-645.

[13]Trinder P. Determination of glucose in blood using an oxidase-peroxidase system with a non-carcinogenic chromogen. J Clin Pathol. 1969:22, 158-161.

[14]Richmond W. Preparation and properties of a cholesterol oxidase from Nocardia sp. and its application to the enzymatic assay of total cholesterol in serum. Clin Chem. 1973:19, 1350-1356.
[15]Siedel, J. Hagele, EO. Ziegenhorn, J. Wahlefeld, AW. Reagent for the enzymatic determination of serum total cholesterol with improved lipolytic efficiency. Clin Chem. 1983:29,1075-1080.

[16]Burstein, M. Scholnick, HR.,Morfin, R. Rapid method for the isolation of lipoproteins from human serum by precipitation with polyanions. J Lipid Res. 1970: 11,583-595. [17]Hatch, FT. Lees, RS. Practical methods for plasma lipoprotein analysis. Adv Lipid Res. 1968.:6: 1-68.

[18]Matthews, DR. Hosker, JP. Rudenski, AS. Naylor, BA. Treacher, DF. Turner, RC. Homeostasis model assessment: insulin resistance and beta cell function from fasting plasma glucose and insulin concentration in man. Diabetologia. 1985: 28, 412-419.

[19]Petridou, E. Mantzoros, CS. Belechri, M. et al. Neonatal leptin levels are strongly associated with female gender, birth length, IGF-I levels and formula feeding. Clin Endocrinol. 2005: 62, 366-371. [20]Haffner, SM. Stern, MP. Miettinen, H. Wei, M. Gingerich, RL. Leptin concentrations in diabetic and nondiabetic Mexican-Americans. Diabetes. 1996:45, 822824.

[21]Widjaja, A. Stratton, IM. Horn, R. Holman, RR. Turner, R. Brabant, G. plasma leptin, obesity, and plasma insulin in type 2 diabetic subjects. J Clin Endocrinol Metab. 1997: 82: 654-657.

[22]Shabana, A. Hasnain, S. The fatty acid binding protein 2 (FABP2) polymorphism Ala54Thr and obesity in Pakistan: a 
population based study and a systematic meta-analysis. Gene. 2015: 574,106-111.

[23]Kasim, NB. Huri, HZ. Vethakkan, SR. Ibrahim, L. Abdullah, BM. Genetic polymorphisms associated with overweight and obesity in uncontrolled Type 2 diabetes mellitus. Biomark Med. 2016:10: 403-415. [24]Kahn, SE. Hull, RL. Utzschneider, KM. Mechanisms linking obesity to insulin resistance and type 2 diabetes. Nature . 2006:444,840-846.

[25]Hoffstedt, J. Eriksson, P. MottaguiTabar, S. Arner, P. A polymorphism in the leptin promoter region (-2548 G/A) influences gene expression and adipose tissue secretion of leptin. Horm Metab Res. 2002:34,355-359.

[26]Wang, TN. Huang, MC. Chang, WT. et al. G-2548A polymorphism of the leptin gene is correlated with extreme obesity in Taiwanese aborigines. Obesity. 2006:14, 183-187.

[27]Duarte, S. Francischetti, EA. Genelhu, VA. Cabello, PH. Pimentel, MMG. LEPR p.Q223R, beta3-AR p.W64R and LEP c.$2548 \mathrm{G}>\mathrm{A}$ gene variants in obese Brazilian subjects. Genet Mol Res. 2008: 6, 10351043.

[28]Hinuy, HM. Hirata, MH. Forti, N. et al. Leptin G-2548A promoter polymorphism is associated with increased plasma leptin and BMI in Brazilian women. Arq Bras Endocrinol. 2008:52, 611-616.

[29]Wauters, M. Considine, RV. Yudkin, JS. Peiffer, F. De Leeuw, I. Van Gaal, LF. Leptin levels in type 2 diabetes: associations with measures of insulin resistance and insulin secretion. Horm Metab Res. 2003:35, 92-96.

[30]Ren, W. Zhang, SH. Wu, J. Ni, YX. Polymorphism of the leptin gene promoter in pedigrees of type 2 diabetes mellitus in Chongqing, China. Chin Med J. 2004:117, 558-561.

[31]Roszkowska-Gancarz, M. Kurylowicz, A. Polosak, J. Mossakowska, M. Franek, E. Puzianowska-Kuznicka, M.. Functional polymorphisms of the leptin and leptin receptor genes are associated with longevity and with the risk of myocardial infarction and of type 2 diabetes mellitus. Endokrynol Pol. 2014:65, 11-16.

[32]Vasku, JA. Vasku, A. Dostalova, Z. Bienert, P. Association of leptin genetic polymorphism -2548 G/A with gestational diabetes mellitus. Genes Nutr. 2006: 1,117123.

[33]Meshkani, R. Nasimian, A. Taheripak, G. Zarghooni, M. Rezaei, M. Sadeghi , A. Zahra Shokati Eshkiki, ZS. Association between Leptin G2548A and Leptin Receptor Q223R Polymorphisms with Type 2 Diabetes in an Iranian Population. Clin. Lab. 2016: 62, 89-96.

[34]Hoffstedt, J. Eriksson, P. MottaguiTabar, S. Arner, P. A polymorphism in the leptin promoter region (-2548 G/A) influences gene expression and adipose tissue secretion of leptin. Horm Metab Res. 2002: 34, 355-359.

[35] Terrasi, M. Fiorio, E. Mercanti, A. et al. Functional analysis of the $2548 \mathrm{G} / \mathrm{A}$ leptin gene polymorphism in breast cancer cells. Int J Cancer. 2009:125, 1038-1044. 